\title{
Quality by Design Approach for Formulation and Optimization of Microparticles Based Inhalable Phytopharmaceuticals of Trigonella Foenum-Graecum and Alpinia Galanga
}

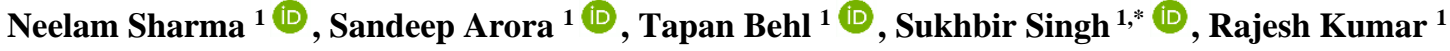 \\ 1 Chitkara College of Pharmacy, Chitkara University, Punjab, India \\ * Correspondence: singh.sukhbir12@gmail.com
}

Scopus Author ID: 56402098100

Received: 3.05.2021; Revised: 1.06.2021; Accepted: 5.06.2021; Published: 18.06.2021

\begin{abstract}
Chronic obstructive pulmonary disease has been the most widespread worldwide health problem that has influenced millions of people worldwide. The freeze-dried inhalable microparticles (FDIMs) of Trigonella foenum-graecum and Alpinia galanga extracts were synthesized by simple emulsification solvent evaporation technique using polyvinyl pyrrolidone K30 (PVP K30) and polyethylene glycol 6000 (PEG 6000) and were optimized using Box-Behnken design (BBD). Mannitol was utilized for surface modification of FDIM for enhancing their aerodynamic characteristics. The independent parameters which were utilized in the optimization strategy were herbal extract: polymer (w/w, X1), mannitol (\% w/v, X2), and surfactant (\% v/v, X3). The studied response variables were mean diameter $(\mu \mathrm{m})(\mathrm{Y} 1)$ and bulk density $(\mathrm{g} / \mathrm{cc})(\mathrm{Y} 2)$. The present study concluded that optimized FDIMs could be successfully manufactured using herbal extract: polymer $(1: 2 \mathrm{w} / \mathrm{w})$, mannitol $(4.616$ $\% \mathrm{w} / \mathrm{v})$ and surfactant $(1.5 \% \mathrm{v} / \mathrm{v})$, which had 0.977 desirability functions. The predicted values of response parameters of optimized FDIMs were found at $1.326 \mu \mathrm{m}$ mean diameter and $0.244 \mathrm{~g} / \mathrm{cc}$ bulk density. The percentage relative error between actual and model-predicted values of mean diameter and bulk density for optimized FDIM was found 4.09 and $2.45 \%$, respectively $(<5 \%)$, which authenticated the articulacy of the optimization approach.
\end{abstract}

Keywords: Alpinia galanga; Box-Behnken design; freeze-dried inhalable microparticles; polyvinyl pyrrolidone K30; polyethylene glycol 6000; Trigonella foenum-graecum.

(C) 2021 by the authors. This article is an open-access article distributed under the terms and conditions of the Creative Commons Attribution (CC BY) license (https://creativecommons.org/licenses/by/4.0/).

\section{Introduction}

The chronic obstructive pulmonary disease has influenced millions of people worldwide and has been the most prevailing worldwide health concern [1,2]. Lungs are important for the exchange of gases and oxygen delivery to all cells. Because of the greater alveolar surface area, rich blood supply, thin blood alveolar boundary, and high permeability, the pulmonary route can non-invasive delivery for systemic and local drug delivery in the respiratory system. This route requires a lower dosage and provides immediate drug release and decreased first-pass hepatic metabolism and adverse effects. As a result, pulmonary drug delivery has attracted attention as a recommended method of treating various respiratory problems. Inhalable microparticles have emerged as a significant advancement in treating 
respiratory ailments [3-15]. The plant extracts-based inhalable microparticles have minimum side effects and have enormous prospects to alleviate pulmonary diseases.

Several techniques for producing inhalable microparticles include emulsion polymerization, dry coating, air suspension, emulsification solvent evaporation technique, freeze-drying, spray drying, and spray freeze drying method [16-18]. The polymers which are commonly used for the production of inhalable microparticles includes 2-hydroxypropyl- $\beta$ cyclodextrin, ascorbic acid, bovine serum albumin, calcium beta-glycerophosphate, chitosan, compritol 888, gelucire-based surfactant, glyceryl behenate, hydroxypropyl- $\beta$-cyclodextrin, lactose, lipoid®-S100, L-leucine, maltodextrin, mannitol, pluronic F-68, poly (D, L-Lactideco-glycolide), poly (l-lactic acid), polyethylene glycol, polyvinyl pyrrolidone, sodium alginate, sodium carboxymethyl cellulose, sodium hyaluronate and starch [19-35].

Trigonella foenum-graecum and Alpinia galanga extracts have been excellent medicine for the management of respiratory problems like asthma, bronchitis, and pleuritic [36-39]. The current research involved manufacturing freeze-dried inhalable microparticles (FDIMs) of Trigonella foenum-graecum and Alpinia galanga extracts, their evaluations, and their qualityby-design optimization. The FDIMs were synthesized using a simple emulsification solvent evaporation technique using polyvinyl pyrrolidone K30 (PVP K30) and polyethylene glycol 6000 (PEG 6000). An optimized batch of FDIMs with minimum particle size and bulk density was explored using the Box-Behnken design (BBD) as required for lung deposition and retention. Mannitol was utilized for surface modification of FDIM for enhancing their aerodynamic characteristics.

\section{Materials and Methods}

\subsection{Materials.}

Trigonella foenum-graecum and Alpinia galanga extracts were purchased from NJP Healthcare Pvt. Ltd. Gujarat. PVP K-30, PEG 6000, mannitol, and tween 80 were procured from Loba Chemicals Private Limited, Mumbai, India. All ingredients employed were of analytical grade.

\subsection{Experimental design.}

The independent and response variables selected for fabrication and optimization of FDIMs are given in Table 1. In the present investigation, FDIMs were manufactured according to 3-factor, 3-level Box-Behnken design (BBD) layout (Table 2), and second-order polynomial was developed by multiple linear regression analysis using Design-Expert software (Trial Version 11.1.2.0, Stat-Ease Inc., MN) [40-45].

Table 1. Composition of freeze-dried inhalable microparticles (FDIMs).

\begin{tabular}{l|l|l|l} 
Independent variables & $\mathbf{- 1}(\mathbf{L o w})$ & $\mathbf{0}($ Medium $)$ & $\mathbf{+ 1}($ High $)$ \\
\hline $\mathrm{X} 1=*$ Herbal extract: Polymer $(\mathrm{w} / \mathrm{w})$ & $1: 2$ & $1: 3$ & $1: 4$ \\
\hline $\mathrm{X} 2=$ Mannitol $(\% \mathrm{w} / \mathrm{v})$ & 2 & 4 & 6 \\
\hline $\mathrm{X} 3=$ Surfactant $(\% \mathrm{v} / \mathrm{v})$ & 0.5 & 1 & 1.5 \\
\hline Response variables & & Constraints & Importance \\
\hline $\mathrm{Y} 1=$ Mean Diameter $(\mu \mathrm{m})$ & & Minimize & +++++ \\
\hline Y2 $=$ Bulk Density $(\mathrm{g} / \mathrm{cc})$ & & Minimize & +++++
\end{tabular}

*Trigonella foenum-graecum and Alpinia galanga extracts in equal proportions. 
Table 2. Box-Behnken design layout for different batches of FDIMs.

\begin{tabular}{l|l|c|c} 
FDIM & Herbal Extract: Polymer $(\mathbf{w} / \mathbf{w})(\mathbf{X} \mathbf{)})$ & Mannitol $(\boldsymbol{\%} \mathbf{w} / \mathbf{v})(\mathbf{X} 2)$ & Surfactant $(\boldsymbol{\%} \mathbf{v} / \mathbf{v})(\mathbf{X 3})$ \\
\hline 1 & -1 & -1 & 0 \\
\hline 2 & 1 & -1 & 0 \\
\hline 3 & -1 & 1 & 0 \\
\hline 4 & 1 & 1 & -1 \\
\hline 5 & -1 & 0 & -1 \\
\hline 6 & 1 & 0 & 1 \\
\hline 7 & -1 & 0 & 1 \\
\hline 8 & 1 & 0 & -1 \\
\hline 9 & 0 & -1 & -1 \\
\hline 10 & 0 & 1 & 1 \\
\hline 11 & 0 & -1 & 1 \\
\hline 12 & 0 & 1 & 0 \\
\hline 13 & 0 & 0 & 0 \\
\hline 14 & 0 & 0 & 0 \\
\hline 15 & 0 & 0 & 0 \\
\hline 16 & 0 & 0 & 0
\end{tabular}

2.3. Fabrication of freeze-dried inhalable microparticles (FDIMs).

The FDIMs were manufactured by quasi-emulsification solvent evaporation technique and lyophilization. The aqueous solution of herbal extracts, mannitol, and tween 80 was prepared. The organic solution of PVP K30 and PEG 6000 was transferred slowly into the aqueous phase and stirred using magnetic stirring (REMI, India) at $2000 \mathrm{rpm}$ for 30 minutes, succeeded by lyophilization (ISIC Make) for 24 hrs to generate fine, porous powder having very less density [46-49].

\subsection{Evaluation of mean diameter (Y1) of FDIMs.}

The mean diameters of FDIMs were determined using an optical microscope outfitted with an ocular micrometer calibrated with a stage micrometer. An overall of 100 microparticles was observed to determine the mean diameter. The observations were performed in triplicate $(\mathrm{n}=3)[50,51]$.

\subsection{Evaluation of bulk density (Y2) of FDIMs.}

The bulk density of FDIMs was determined using a $10 \mathrm{~mL}$ graduated cylinder. 1 gram of FDIMs was poured into the cylinder, and bulk density was calculated using equation 1 [5254].

Bulk density $(\mathrm{g} / \mathrm{cc})=\frac{\text { Weight of powder }(\mathrm{gm})}{\text { Volume of powder }(\mathrm{cc})}$

2.6. Fit summary and lack of fit test analysis for selection of appropriate model by Design-Expert Software.

Using Design-Expert Software, fit summary and lack of fit test were applied in order to select the appropriate model out of linear, 2-factor interaction (2FI), quadratic and cubic models. The highest-order polynomial where the additional terms were significant and the model was not aliased was selected. The model which maximizes the adjusted and predicted regression coefficient was focused on model selection. Another criterion for model selection 
was that the selected model should have an insignificant lack-of-fit ( $p>0.05)$ and the highest $\mathrm{R}^{2}$ value. Predicted residual error sum of squares (PRESS) statistics were utilized to crossvalidation the selected regression model on the criterion of least PRESS value [55-57].

2.7. Analysis of variance (ANOVA), diagnostic and response surface analysis of mean diameter $(\mu \mathrm{m})(Y 1)$ and bulk density $(\mathrm{g} / \mathrm{cc})(\mathrm{Y} 2)$ by Design-Expert Software.

ANOVA for the quadratic model was applied for the determination of the sum of squares, mean square, F-value, and p-value for the model, X1, X2, X3, X1X2, X2X3, X1X3, $\mathrm{X} 1^{2}, \mathrm{X} 2^{2}, \mathrm{X} 3^{2}$ and lack of fit to find out significant independent parameters which affect response variables ( $\mathrm{p}$-value < 0.05 ). The quadratic equations for $\mathrm{Y} 1$ and $\mathrm{Y} 2$ were developed to estimate the main interaction and quadratic effects of independent parameters on mean diameter $(\mu \mathrm{m})(\mathrm{Y} 1)$ and bulk density (g/cc) (Y2). Diagnostic plots were developed by DesignExpert software to investigate the goodness of fit of the proposed model. Three-dimensional response surface graphs and corresponding two-dimensional contour graphs were developed using the Design-Expert Software model graph tool (Trial Version 11.1.2.0, Stat-Ease Inc., $\mathrm{MN}$ ) to evaluate the impact of independent variables on dependent parameters [58-62].

\subsection{Numerical and graphical optimization of FDIMs.}

Optimal values of formulation and process variables for the manufacture of FDIM were acquired using the Design-Expert software on the set paradigm of minimizing mean diameter $(\mu \mathrm{m})(\mathrm{Y} 1)$ and bulk density $(\mathrm{g} / \mathrm{cc})(\mathrm{Y} 1)$. This involved setting parameters for optimization, followed by running optimization to produce a view of numerical ramps for optimization. Design-expert ® 11.1.2.0 Software generated report of optimized formulation and process conditions for the optimal formulation of FDIM along with predicted values of dependent variables. To acquire graphical view of region corresponding to highest overall desirability function, a three-dimensional response surface graph and corresponding contour plot were generated [63].

\subsection{Checkpoint analysis.}

Using Design-expert @ 11.1.2.0 software, optimum formulation variables were acquired to synthesize optimized FDIM with the highest desirability coefficient. To validate the optimization technique, the FDIM checkpoint batch was synthesized using optimal variables values and evaluated for mean diameter $(\mu \mathrm{m})(\mathrm{Y} 1)$ and bulk density $(\mathrm{g} / \mathrm{cc})(\mathrm{Y} 2)$. The percentage of relative error between experimental and predicted values of dependent variables was determined for optimized FDIM using the following equation [63].

$$
\% \text { Relative error }=\frac{\mid \text { Predicted value }- \text { Experimental value } \mid}{\text { Predicted value }} \times 100
$$

\subsection{Characterization of optimized FDIM.}

2.10.1. Production yield.

The production yield (\%) was determined after weighing the recovered FDIMs (practical yield) using the following formula [64]:

$$
\text { Yield }=\frac{\text { Practical yield }}{\text { Theoretical yield }} \times 100
$$




\subsubsection{Micromeretic properties.}

The micrometric characteristics of FDIMs were performed to assess the physical appearance and flowability behavior to verify their appropriateness for inhalation [65-67]. A weighed quantity of FDIMs was poured into a graduated cylinder to determine the bulk and tapped density using tapped density tester. A static funnel technique was utilized to estimate the angle of repose. Bulk characterization considerations were performed to investigate flow characteristics using the following formulas.

$$
\begin{array}{ll}
\text { Bulk density }\left(\frac{\mathrm{g}}{\mathrm{cc}}\right)=\frac{\text { Weight of FDIMs }}{\text { Bulk Volume }} & \text { Eq. (4) } \\
\text { Tapped density }\left(\frac{\mathrm{g}}{\mathrm{cc}}\right)=\frac{\text { Weight of FDIMs }}{\text { Tapped Volume }} & \text { Eq. (5) } \\
\text { Carr's Index }(\%)=\frac{\text { Tapped density-Bulk density }}{\text { Tapped Density }} \times 100 & \text { Eq. (6) } \\
\text { Angle of repose }(\theta)=\tan ^{-1}\left(\frac{\text { Height of pile }}{\text { Radius of pile }}\right) & \text { Eq. (7) }
\end{array}
$$

2.10.3. Dynamic light scattering (DLS).

The mean diameter of FDIMs was assessed using the dynamic light scattering technique using Beckman Coulter, Version 3.73/2.30 (USA). In brief, FDIMs were dispersed in distilled water in a quartz cuvette and analyzed at $25^{\circ} \mathrm{C}[68,69]$.

\subsubsection{Stability study.}

The optimized FDIMs were filled in $5 \mathrm{ml}$ amber color vials, sealed with a rubber closure, and crimped with an aluminum over-seal. The filled and sealed vials were placed in Remi stability chamber; model SC-10 Plus at $25 \pm 2^{\circ} \mathrm{C} / 60 \pm 5 \% \mathrm{RH}$ and $40 \pm 2^{\circ} \mathrm{C} / 75 \pm 5 \% \mathrm{RH}$. After the preliminary examination of stability parameters, i.e., mean diameter, bulk density, tapped density, Carr's index, Hausner's ratio, and angle of repose. The vials were periodically sampled at 15, 30, 45, 60, and 90 days. The FDIMs were assessed for observing any change in stability parameters [70-74].

\subsection{Statistical analysis.}

The statistical analysis of polynomial equations was carried out by using the analysis of variance (ANOVA) tool in Design-Expert software (Trial Version 11.1.2.0, Stat-Ease Inc., $\mathrm{MN}$ ). All other data were analyzed by two-way ANOVA using GraphPad Prism version 6.01 (GraphPad Software, San Diego, California, USA). The statistical difference was considered significant $(\mathrm{p}<0.05)$.

\section{Results and discussions}

\section{1. $\quad$ Fit summary and lack of fit test analysis for selection of appropriate model by} Design-Expert Software.

Results of the fit summary and lack of fit test have been depicted in Tables 3 and 4. Results illustrates that sequential p-value was significant for linear $(<0.0001$ for Y1; 0.0002 for Y2) and quadratic models ( $<0.0001$ for Y1; 0.0078 for Y2). Lack of fit p-value was insignificant only for quadratic models ( 0.3608 for $\mathrm{Y} 1 ; 0.9239$ for $\mathrm{Y} 2)$. The $\mathrm{R}^{2}$ value for mean 
diameter (Y1) for linear, 2 FI, quadratic, and cubic models was 0.9227, 0.9267, 0.9959, and 0.9980 . $\mathrm{R}^{2}$ value for bulk density (Y2) for linear, $2 \mathrm{FI}$, quadratic and cubic models were 0.7635 , $0.7880,0.9574$, and 0.9618 , respectively. The highest $\mathrm{R}^{2}$ value was for quadratic and cubic models, while the predicted R2 value was not found for the cubic model. Therefore, cubic models were aliased by Design-Expert, and ultimately quadratic models were selected for further analysis by software. The best fitting of quadratic models was confirmed by predicted $\mathrm{R}^{2}$, adjusted $\mathrm{R}^{2}$, and PRESS values. The predicted $\mathrm{R}^{2}$ of $0.9632(\mathrm{Y} 1)$ and $0.8710(\mathrm{Y} 2)$ were in reasonable agreement with the adjusted $\mathrm{R}^{2}$ of 0.9907 (Y1) and 0.9027 (Y2), i.e., the difference is less than 0.2. Moreover, the quadratic model has the smallest PRESS values for Y1 (2.75) and Y2 (0.0544) [55-57].

Table 3. Fit summary analysis for mean diameter ( $\mu \mathrm{m})(\mathrm{Y} 1)$ and bulk density (g/cc) (Y2).

\begin{tabular}{l|l|l|l|l|l|l|l}
\multirow{2}{*}{ Response } & Source & $\begin{array}{l}\text { Sequential } \\
\text { p-value }\end{array}$ & $\begin{array}{l}\text { Lack of Fit } \\
\text { p-value }\end{array}$ & $\mathbf{R}^{\mathbf{2}}$ & Adjusted $\mathbf{R}^{\mathbf{2}}$ & Predicted R $^{\mathbf{2}}$ & PRESS \\
\hline \multirow{3}{*}{ Y1 } & Linear & $<0.0001$ & 0.0076 & 0.9227 & 0.9048 & 0.8718 & 9.59 \\
\cline { 2 - 9 } & 2FI & 0.9050 & 0.0042 & 0.9267 & 0.8827 & 0.7635 & 17.70 \\
\cline { 2 - 9 } & Quadratic & $<0.0001$ & 0.3608 & 0.9959 & 0.9907 & 0.9632 & 2.75 \\
\hline \multirow{2}{*}{ Y2 } & Linear & 0.0002 & 0.2187 & 0.7635 & 0.7089 & 0.5853 & 0.1749 \\
\cline { 2 - 8 } & 2FI & 0.7655 & 0.1514 & 0.7880 & 0.6609 & 0.2449 & 0.3184 \\
\cline { 2 - 8 } & Quadratic & 0.0078 & 0.9239 & 0.9574 & 0.9027 & 0.8710 & 0.0544
\end{tabular}

Table 4. Lack of fit tests for mean diameter ( $\mu \mathrm{m})(\mathrm{Y} 1)$ and bulk density (g/cc) (Y2).

\begin{tabular}{l|l|l|l|l|l} 
Response & Source & Sum of Squares & Mean Square & F-value & p-value \\
\hline \multirow{3}{*}{ Y1 } & Linear & 5.64 & 0.6266 & 16.93 & 0.0076 \\
\cline { 2 - 6 } & 2FI & 5.34 & 0.8895 & 24.04 & 0.0042 \\
\cline { 2 - 6 } & Quadratic & 0.1575 & 0.0525 & 1.42 & 0.3608 \\
\hline \multirow{3}{*}{ Y2 } & Linear & 0.0836 & 0.0093 & 2.31 & 0.2187 \\
\cline { 2 - 6 } & 2FI & 0.0733 & 0.0122 & 3.03 & 0.1514 \\
\cline { 2 - 6 } & Quadratic & 0.0018 & 0.0006 & 0.1510 & 0.9239
\end{tabular}

3.2. Analysis of variance, diagnostic and response surface analysis of mean diameter $(\mu \mathrm{m})(Y 1)$ and bulk density $(\mathrm{g} / \mathrm{cc})(Y 2)$ by Design-Expert Software.

The model F-value for Y1 was 189.72 ( $\mathrm{p}<0.0001$ ), and for $\mathrm{Y} 2$ was $17.5(\mathrm{p}<0.05)$, which implies that the quadratic model is significant. The lack of fit F-value for Y1 was 1.42 ( $p>0.05)$ and for Y2 was $0.15(\mathrm{p}>0.05)$, which implied that lack of fit is not significant relative to the pure error (Table 5). Figures $1 \mathrm{a}$ and 2a depicted normal probability plots, which illustrated that the utmost color points depicting Y1 and Y2 were positioned on a typical probability line, demonstrating normality in responses. Figures $1 \mathrm{~b}$ and $2 \mathrm{~b}$ showed externally studentized residuals versus the predicted plot, which indicated that color points corresponding to Y1 and Y2 were in proximity to the zero-axis, which displayed the lack of constant error. Figures $1 \mathrm{c}$ and $2 \mathrm{c}$ investigated residual versus run graphs to search for the prominent variable that could have profoundly affected Y1 and Y2 throughout the investigation. Predicted versus actual plot portrayed in Figures $1 \mathrm{~d}$ and $2 \mathrm{~d}$ demonstrated a significant linear graph running via the origin, which meant that measured data of $\mathrm{Y} 1$ and $\mathrm{Y} 2$ significantly correlated with expected values [58-62].

Independent factors affecting the mean diameter $(\mu \mathrm{m})$ of FDIMs were herbal extract: polymer (X1) and surfactant (X3) $(p<0.01)$, which can be elucidated by Eq. (8) and has been depicted in Figure 3.

$$
\begin{aligned}
\mathrm{Y} 1= & 3.58+2.91 \mathrm{X} 1-0.125 \mathrm{X} 2-0.363 \mathrm{X} 3-0.05 \mathrm{X} 1 \mathrm{X} 2+0.225 \mathrm{X} 1 \mathrm{X} 3+0.15 \mathrm{X} 2 \mathrm{X} 3+1.02 \\
& \mathrm{X} 1^{2}+0.297 \mathrm{X} 2^{2}+0.17 \mathrm{X} 3^{2}
\end{aligned}
$$


The negative and positive coefficients before independent variables pinpoint negative and positive effects on response variables, respectively. Independent factors affecting bulk density (g/cc) of FDIMs were herbal extract: polymer (X1) and surfactant (X3) $(p<0.01)$, which can be elucidated by Eq. (9) and has been depicted in Figure 4.

$$
\begin{gathered}
\mathrm{Y} 2=0.376+0.198 \mathrm{X} 1+0.0075 \mathrm{X} 2-0.0263 \mathrm{X} 3-0.0125 \mathrm{X} 1 \mathrm{X} 2+0.025 \mathrm{X} 1 \mathrm{X} 3-0.0425 \\
\mathrm{X} 2 \mathrm{X} 3+0.1295 \mathrm{X}^{2}+0.007 \mathrm{X} 2^{2}-0.0055 \mathrm{X}^{2}
\end{gathered}
$$

Table 5. Analysis of variance for quadratic model for mean diameter $(\mu \mathrm{m})(\mathrm{Y} 1)$ and bulk density $(\mathrm{g} / \mathrm{cc})(\mathrm{Y} 2)$.

\begin{tabular}{l|l|l|l|l|l|l|l|l|l} 
Source & df & \multicolumn{2}{l}{ Sum of Squares } & \multicolumn{2}{l}{ Mean Square } & \multicolumn{2}{l}{ F-value } & \multicolumn{2}{l}{ p-value } \\
\hline & & Y1 & Y2 & Y1 & Y2 & Y1 & Y2 & Y1 & Y2 \\
\hline Model & 9 & 74.52 & 0.4038 & 8.28 & 0.0449 & 189.72 & 17.50 & $<0.0001^{*}$ & $0.005^{*}$ \\
\hline $\mathrm{X} 1$ & 1 & 67.86 & 0.3160 & 67.86 & 0.3160 & 1554.92 & 123.27 & $<0.0001^{*}$ & $<0.0001^{*}$ \\
\hline $\mathrm{X} 2$ & 1 & 0.1250 & 0.0005 & 0.1250 & 0.0005 & 2.86 & 0.1755 & 0.1344 & 0.6878 \\
\hline $\mathrm{X} 3$ & 1 & 1.05 & 0.0055 & 1.05 & 0.0055 & 24.09 & 2.15 & $0.0017^{*}$ & 0.1860 \\
\hline $\mathrm{X} 1 \mathrm{X} 2$ & 1 & 0.0100 & 0.0006 & 0.0100 & 0.0006 & 0.2291 & 0.2438 & 0.6468 & 0.6366 \\
\hline $\mathrm{X} 1 \mathrm{X} 3$ & 1 & 0.2025 & 0.0025 & 0.2025 & 0.0025 & 4.64 & 0.9752 & 0.0682 & 0.3563 \\
\hline $\mathrm{X} 2 \mathrm{X} 3$ & 1 & 0.0900 & 0.0072 & 0.0900 & 0.0072 & 2.06 & 2.82 & 0.1941 & 0.1371 \\
\hline $\mathrm{X} 1^{2}$ & 1 & 4.40 & 0.0706 & 4.40 & 0.0706 & 100.87 & 27.54 & $<0.0001^{*}$ & $0.0012^{*}$ \\
\hline $\mathrm{X} 2^{2}$ & 1 & 0.3727 & 0.0002 & 0.3727 & 0.0002 & 8.54 & 0.0805 & 0.0223 & 0.7849 \\
\hline $\mathrm{X} 3^{2}$ & 1 & 0.1253 & 0.0001 & 0.1253 & 0.0001 & 2.87 & 0.0497 & 0.1340 & 0.8300 \\
\hline Lack of Fit & 3 & 0.1575 & 0.0018 & 0.0525 & 0.0006 & 1.42 & 0.1510 & 0.3608 & 0.9239
\end{tabular}

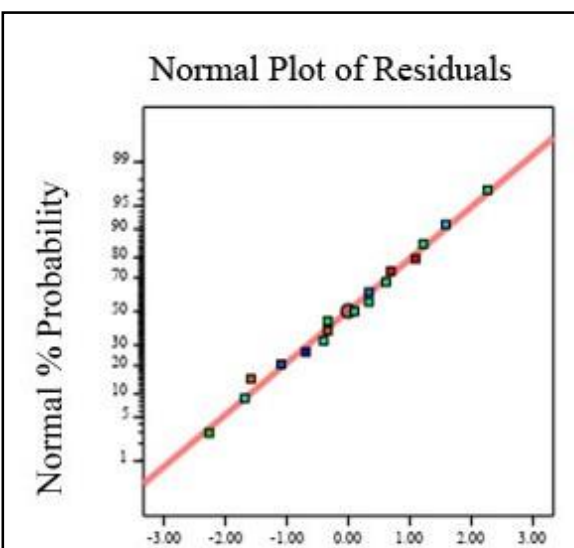

Externally Studentized Residuals

(a)

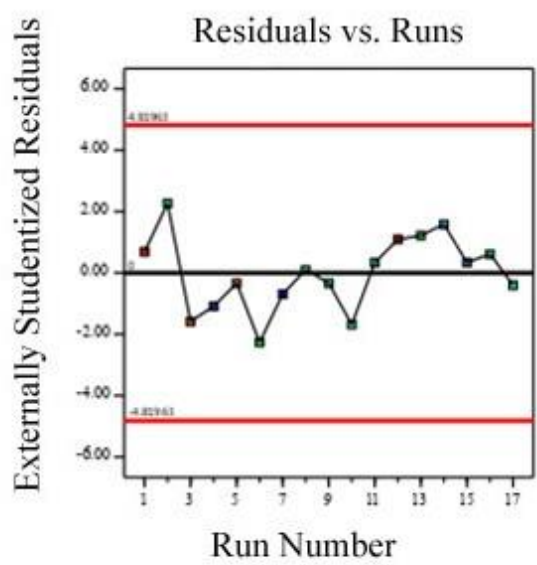

(c)

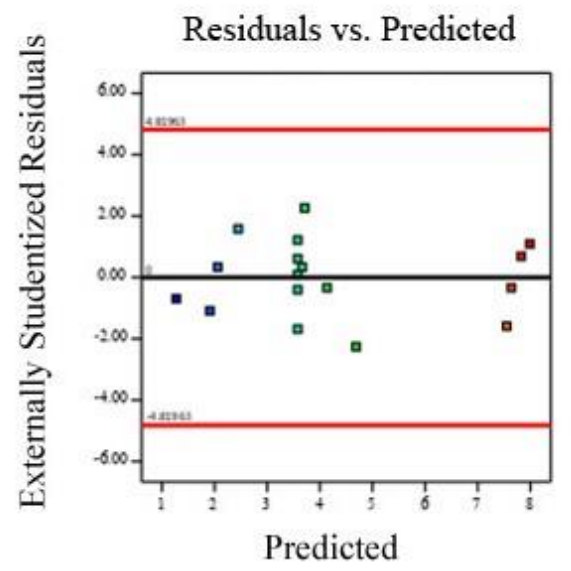

(b)

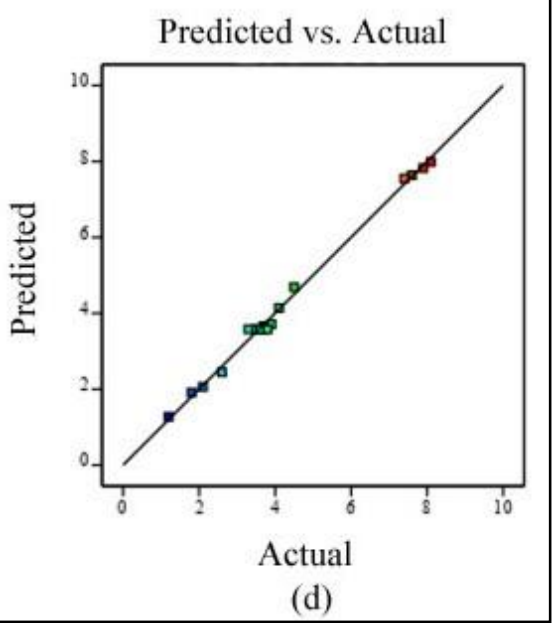

(d)

Figure 1. Diagnostic plot for mean diameter $(\mu \mathrm{m})(\mathrm{Y} 1)$ 


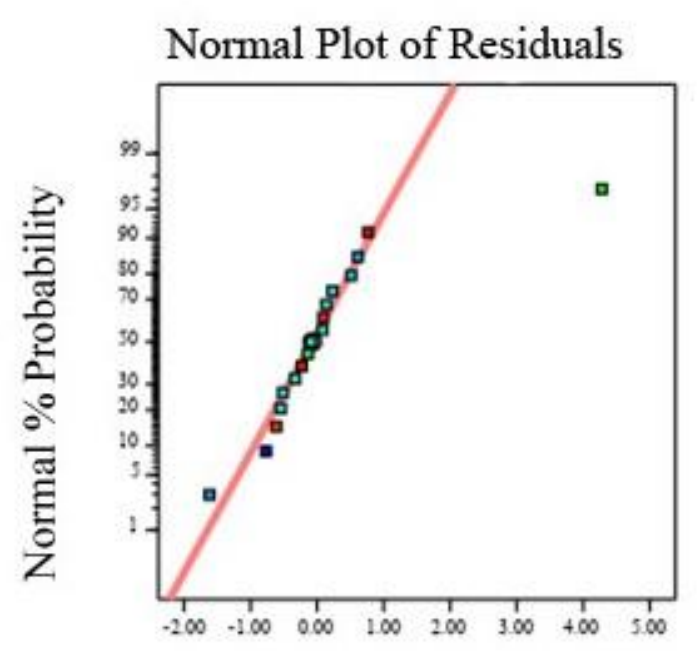

Externally Studentized Residuals

(a)

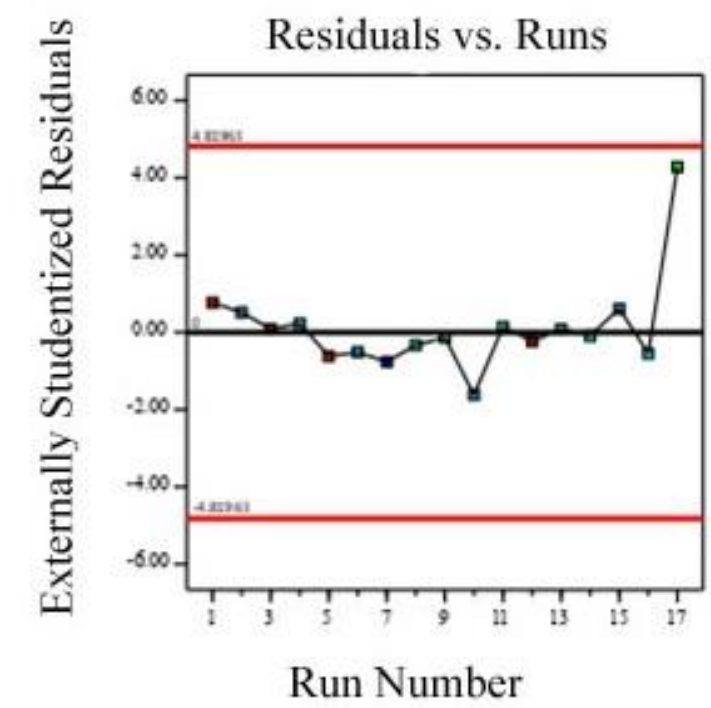

(c)

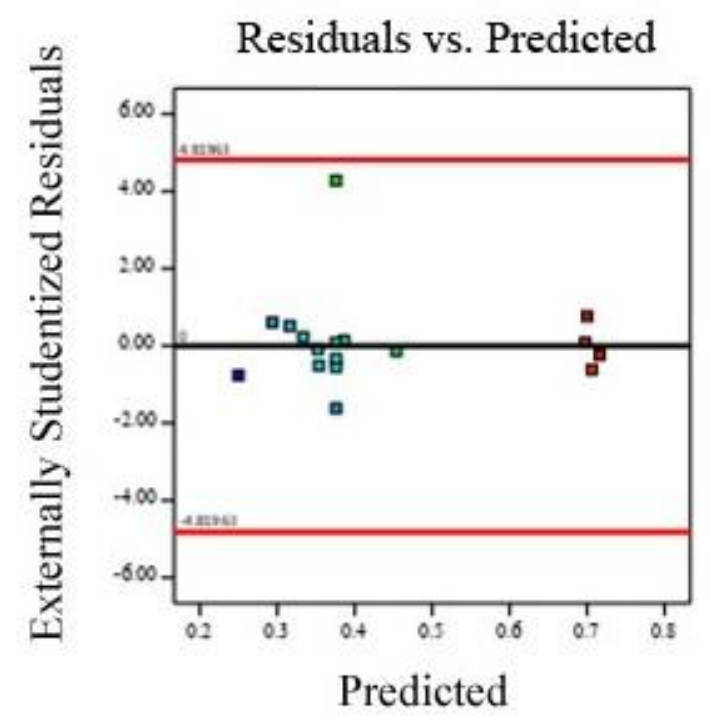

(b)

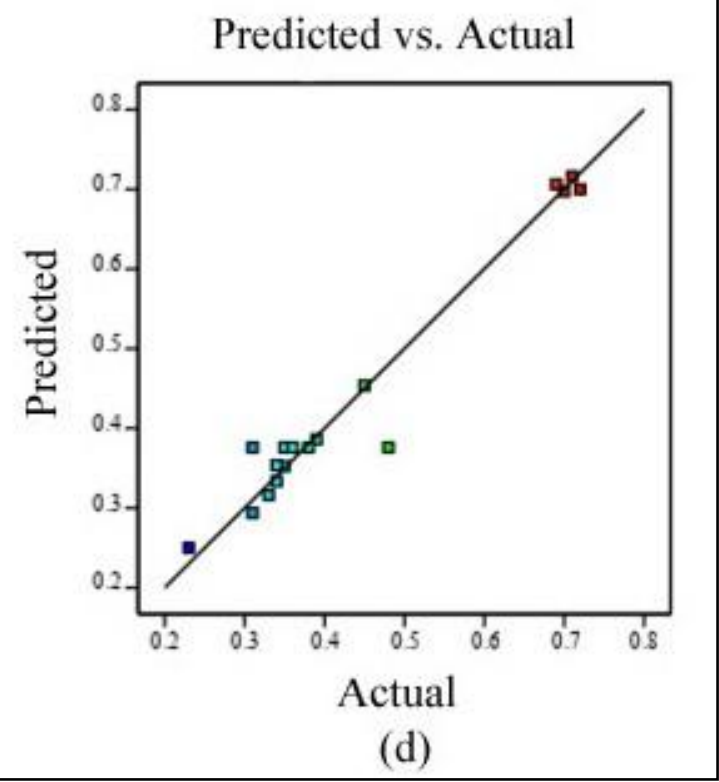

(d)

Figure 2. Diagnostic plot for bulk density (g/cc) (Y2).

\subsection{Numerical and graphical optimization of FDIMs.}

Using Design-Expert Software (Trial Version 11.1.2.0, Stat-Ease Inc., MN), an optimized FDIM batch explored the desirability function and composition for optimized FDIM has been depicted in Table 6 and Figure 5. Ramps are a graphical view of each optimal solution. Optimal factor settings are shown with red points. Optimal response prediction values are displayed in blue (Figure 6) [63]. Overlay plots demonstrating optimal composition of independent parameters (coded) and responses of optimized FDIM are given in Figure 7.

Table 6. Optimized FDIM as per the Design-expert ${ }^{\circledR}$ 11.1.2.0 software.

\begin{tabular}{l|l|c|l|c} 
Independent variables & Criteria & Importance & Value & $\phi$ Desirability \\
\hline $\mathrm{X} 1=*$ Herbal Extract: Polymer $(\mathrm{w} / \mathrm{w})$ & In range & +++ & $1: 2$ & \\
\hline $\mathrm{X} 2=$ Mannitol $(\% \mathrm{w} / \mathrm{v})$ & In range & +++ & 4.616 & \\
\hline $\mathrm{X} 3=$ Surfactant $(\% \mathrm{v} / \mathrm{v})$ & In range & +++ & 1.5 & \\
\hline Response variables & & & \multicolumn{2}{|l}{ Predicted values } \\
\hline $\mathrm{Y} 1=$ Mean Diameter $(\mu \mathrm{m})$ & Minimize & +++++ & 1.326 & \\
\hline $\mathrm{Y} 2=$ Bulk Density $(\mathrm{g} / \mathrm{cc})$ & Minimize & +++++ & 0.244 & 0.977
\end{tabular}



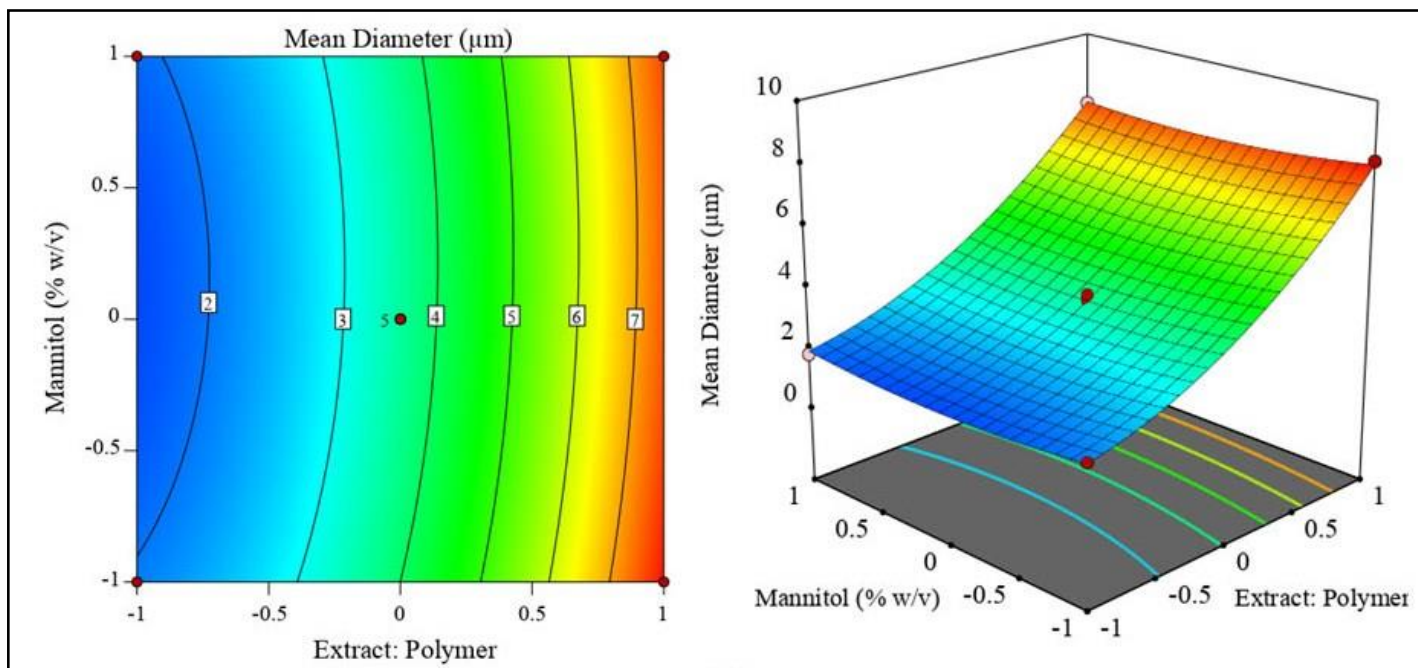

(a)
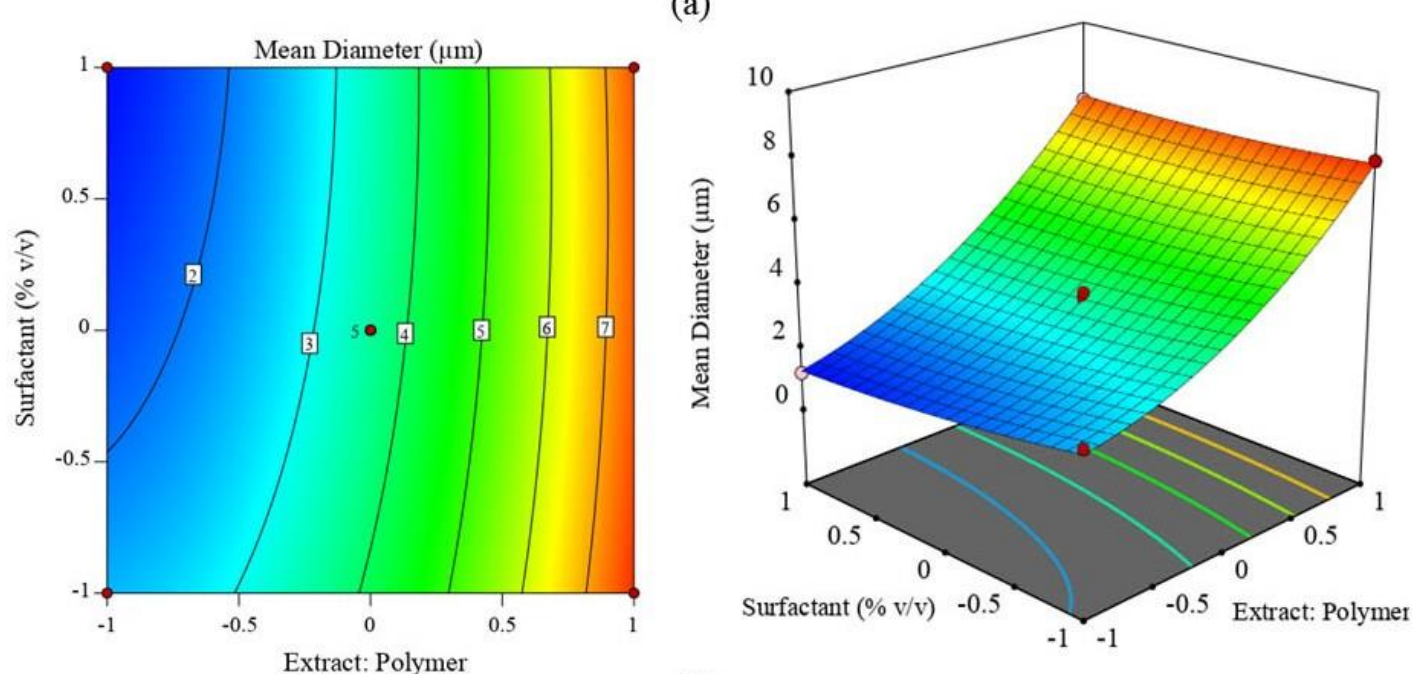

(b)
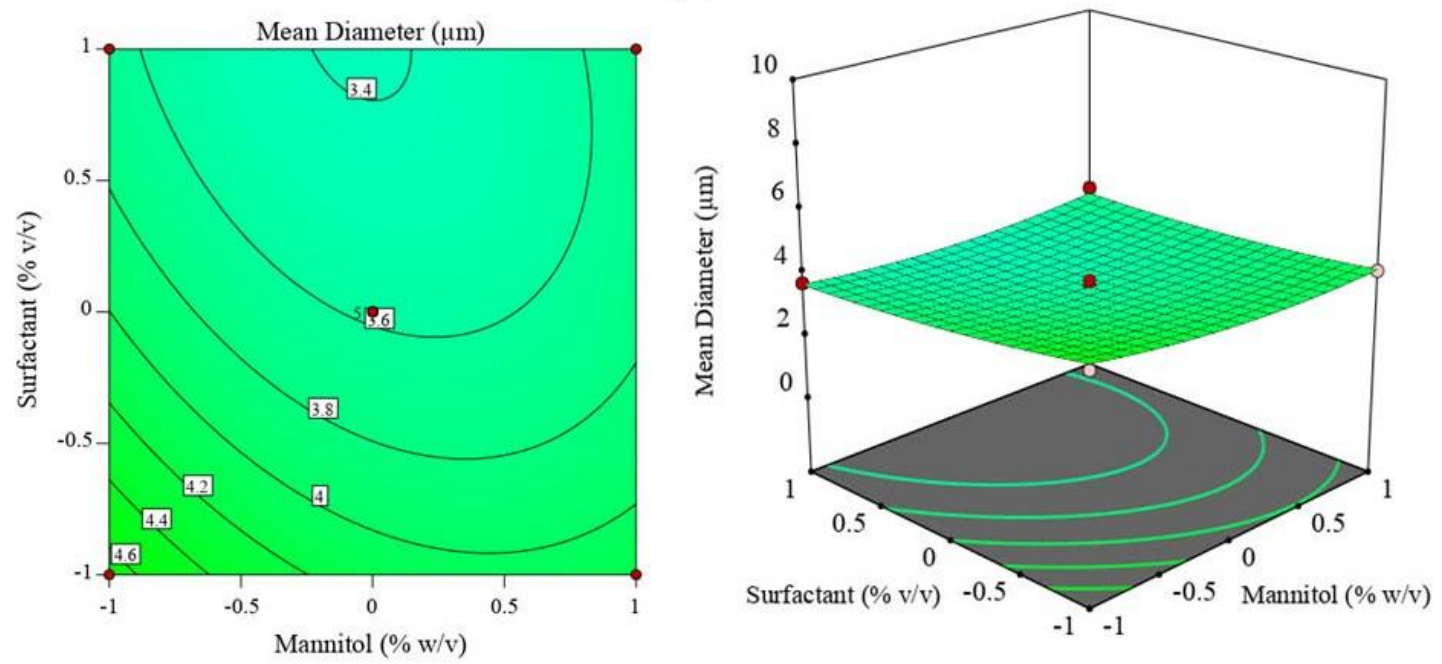

(c)

Figure 3. Contour (2D) and response surface plot (3D) showing the effect of independent variables on mean diameter $(\mu \mathrm{m})(\mathrm{Y} 1)$. 

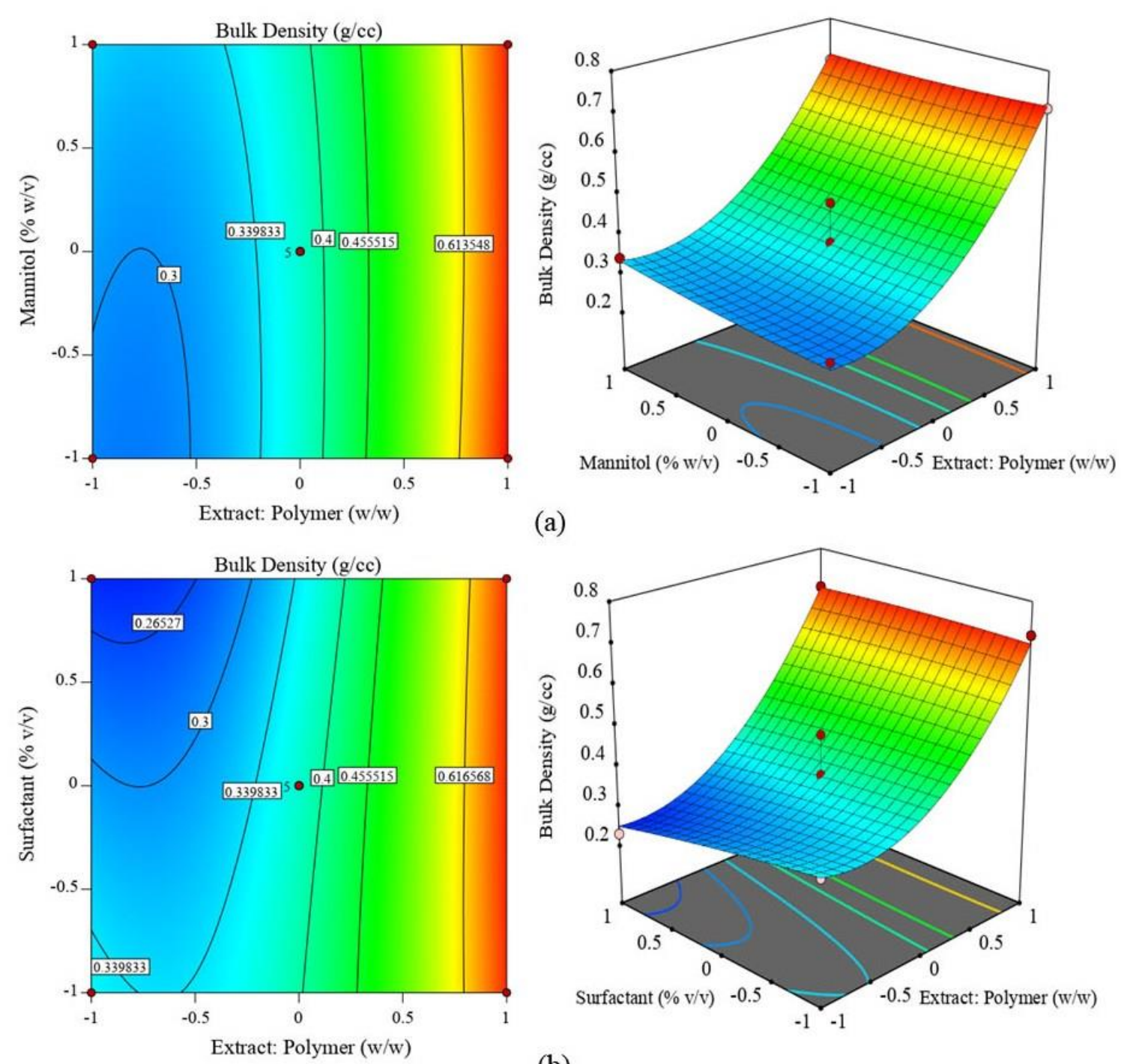

(a)

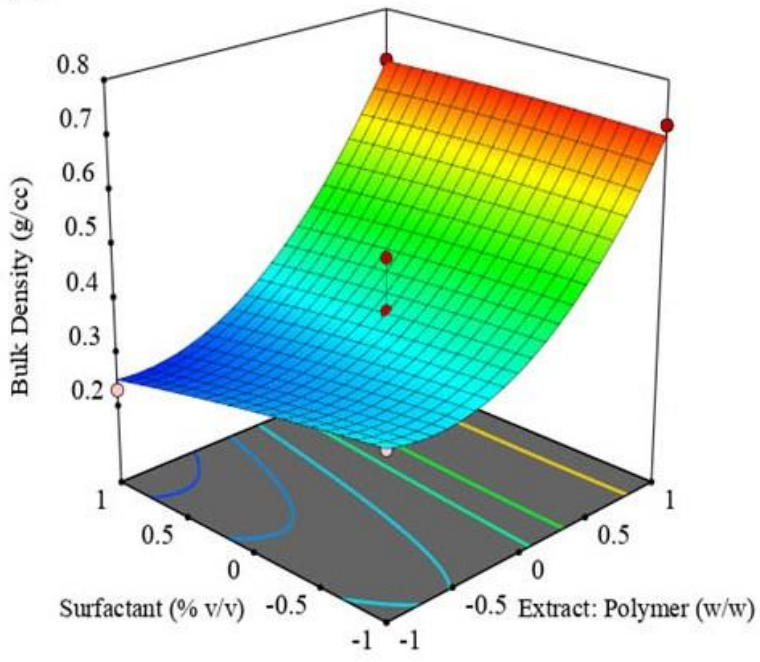

(b)
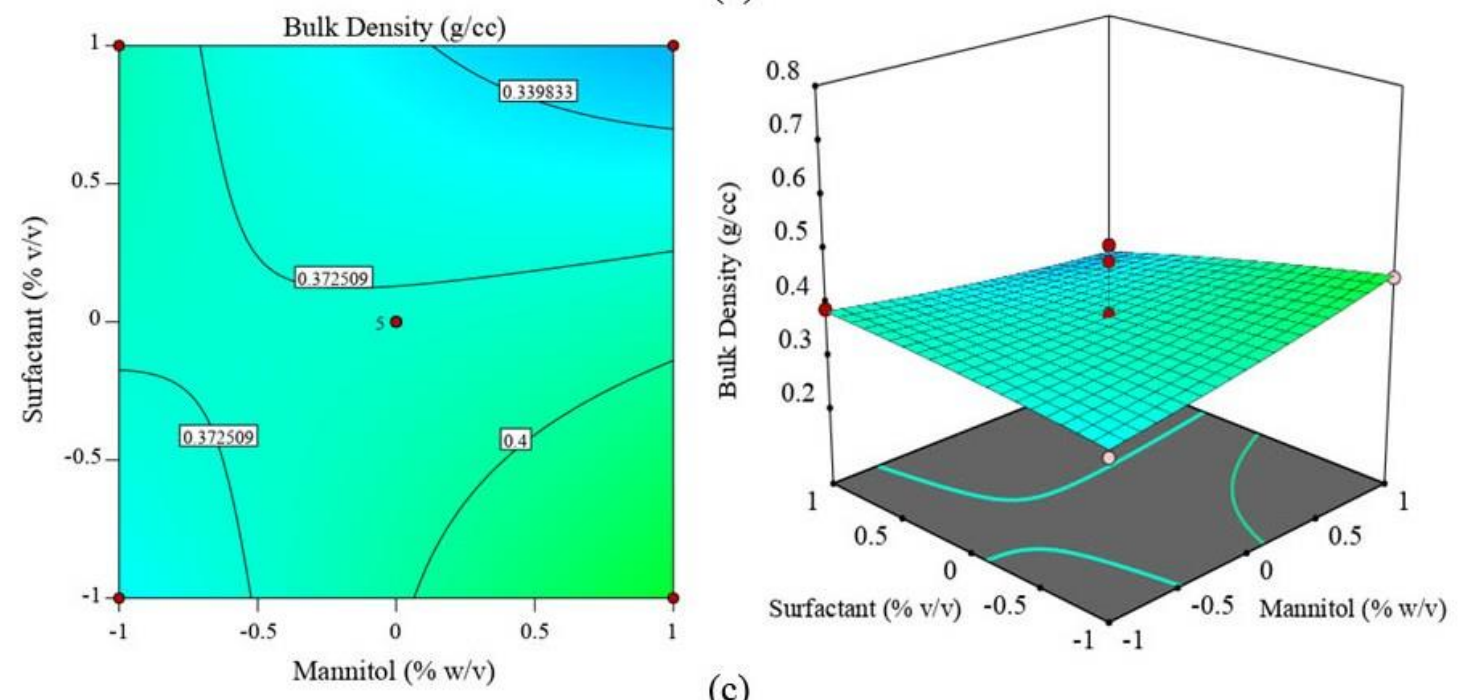

(c)

Figure 4. Contour (2D) and response surface plot (3D) showing the effect of independent variables on bulk density (g/cc) (Y2). 


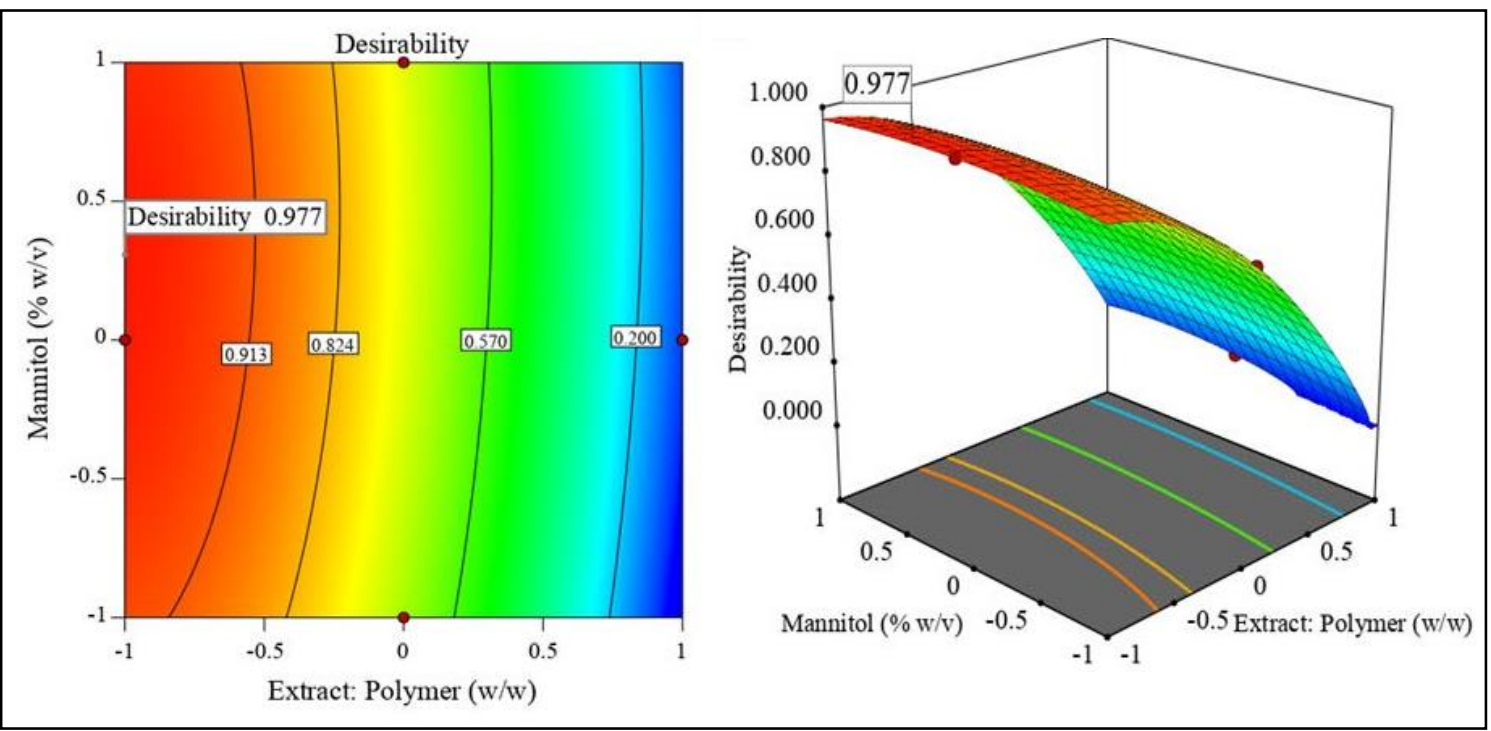

Figure 5. Contour and response surface plot showing desirability function of optimized FDIM.
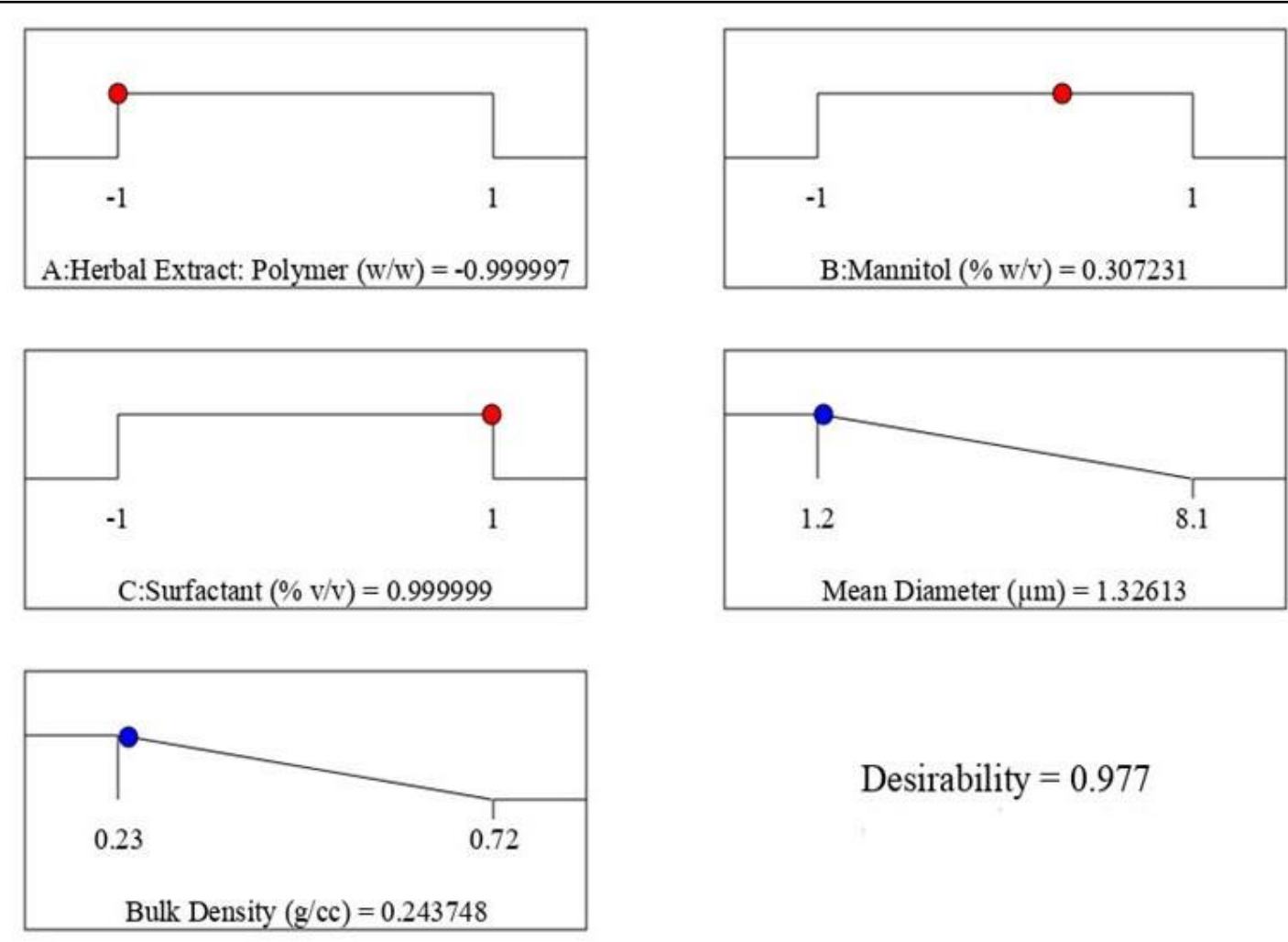

Desirability $=0.977$

Figure 6. Numerical optimization ramps graph showing desirability function of optimized FDIM.

\subsection{Checkpoint analysis.}

An additional batch of optimized FDIM with herbal extract: polymer (w/w) $(\mathrm{X} 1=1: 2)$, mannitol $(\% \mathrm{w} / \mathrm{v})(\mathrm{X} 2=4.616)$, and surfactant $(\% \mathrm{v} / \mathrm{v})(\mathrm{X} 3=1.5)$ were produced and evaluated for mean diameter and bulk density. The actual mean diameter and bulk density of optimized FDIMs were found $1.38 \mu \mathrm{m}$ and $0.238 \mathrm{~g} / \mathrm{cc}$, respectively. The percentage relative error between actual and model-predicted values of mean diameter $(\mu \mathrm{m})(\mathrm{Y} 1)$ and bulk density $(\mathrm{g} / \mathrm{cc})(\mathrm{Y} 2)$ for optimized FDIM was found 4.09 and $2.45 \%$, respectively $(<5 \%)$, which authenticated articulacy of the optimization approach [63]. 


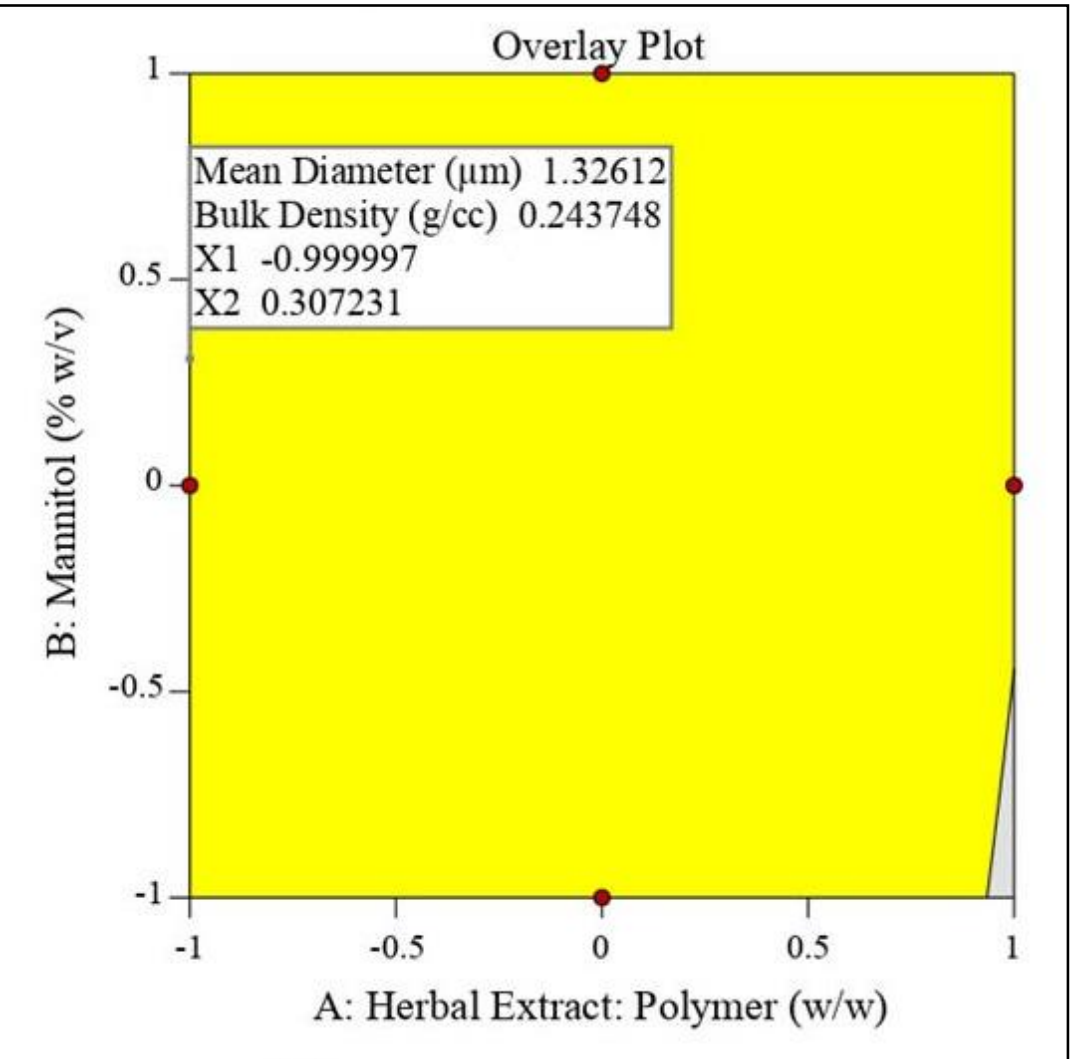

Figure 7. Overlay plot displaying optimal values of independent (coded) and response parameters of optimized FDIM.

\subsection{Production yield of optimized FDIMs.}

The production yield (\%) of optimized FDIMs prepared using herbal extract: polymer $(1: 2)$, mannitol $(4.616 \% \mathrm{w} / \mathrm{v})$ and surfactant $(1.5 \% \mathrm{v} / \mathrm{v})$ was found $83.21 \%$. The loss during the manufacturing process might be due to the adhering of some polymer solutions to a glass container and loss during removal of the product from the round bottom flask after freezedrying [64].

\subsection{Micromeretic characteristics.}

The physical appearance of FDIMs was found free flowing powder with $0.238 \mathrm{~g} / \mathrm{cc}$ bulk density, $0.263 \mathrm{~g} / \mathrm{cc}$ tapped density, $9.5 \%$ Carr's index, and $15.36^{\circ}$ angle of repose. Carr's index and angle of repose of FDIMs were less than $15 \%$ and $25^{\circ}$, respectively, which indicated excellent flowability of FDIMs and verified that these could be effectively utilized for inhalation [65-67].

\subsection{Dynamic light scattering (DLS).}

The mean diameter (z-average) of optimized FDIMs was found at $1.152 \mu \mathrm{m}$, which was in micrometer size at a smaller scale which could be attributable to a reduction in surface tension over the surface of particles by tween 80 (Figure 8) [68,69]. 


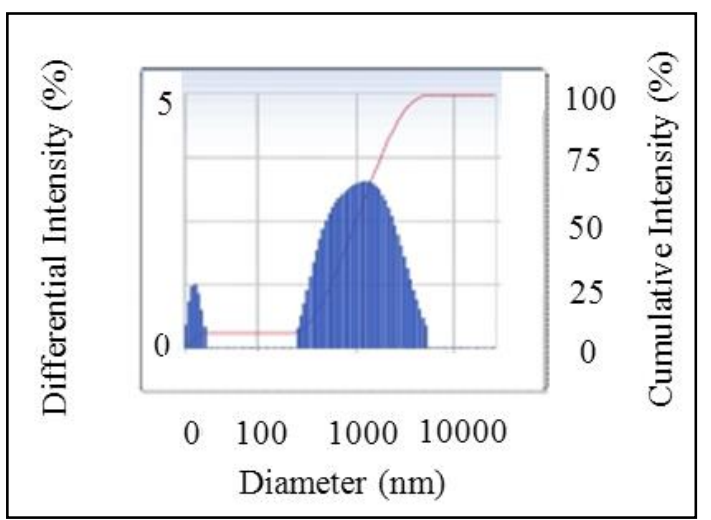

Figure 8. Intensity distributions analysis of optimized FDIMs.

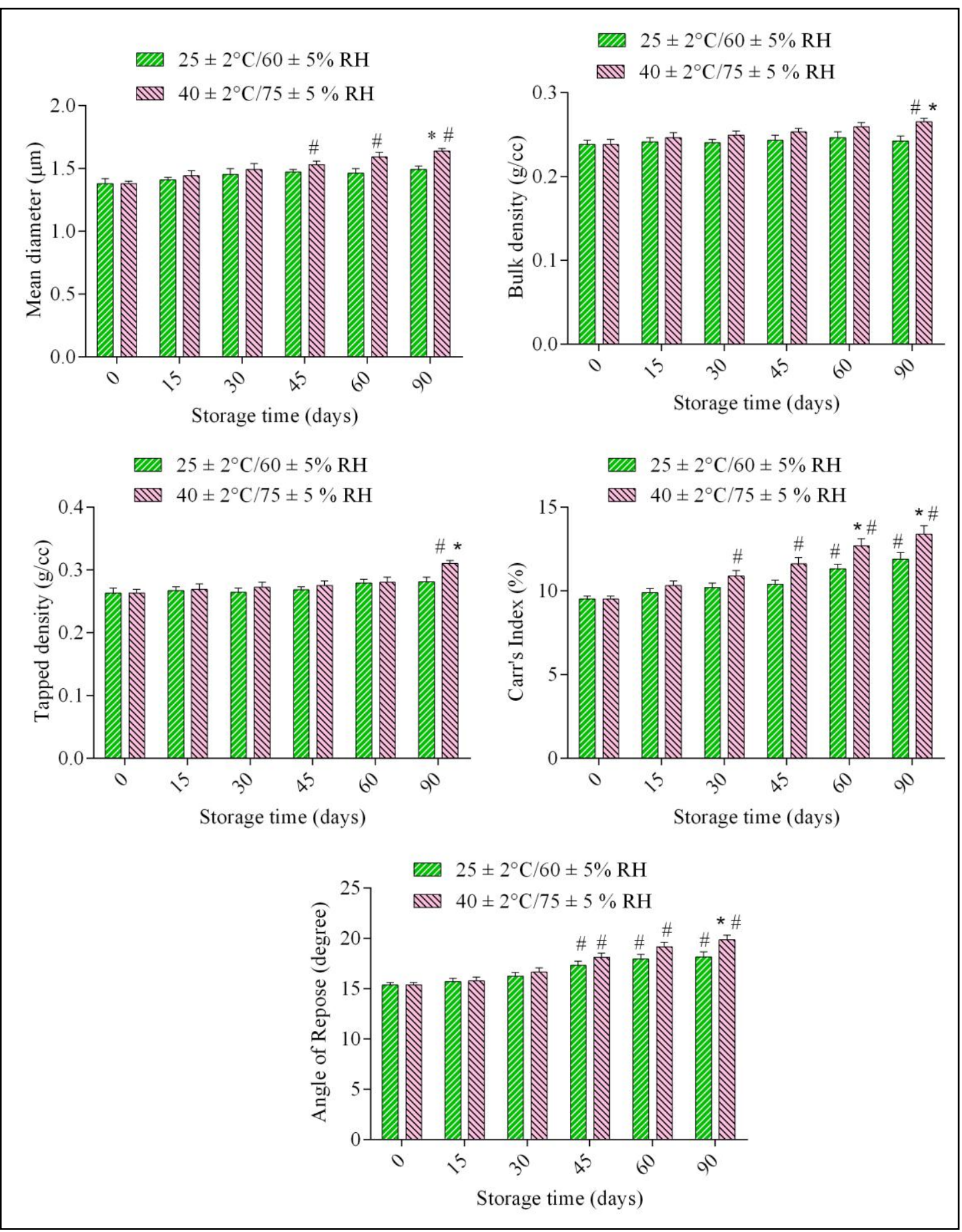

Figure 9. Stability studies evaluation of FDIMs. ${ }^{*} \mathrm{p}<0.05$ significant difference between $25 \pm 2{ }^{\circ} \mathrm{C} / 60 \pm 5 \% \mathrm{RH}$ versus $40 \pm 2^{\circ} \mathrm{C} / 75 \pm 5 \% \mathrm{RH} ; \# 0<0.05$ significant difference in comparison to day 0 . 


\subsection{Stability study.}

The FDIMs stored at $25 \pm 2^{\circ} \mathrm{C} / 60 \pm 5 \% \mathrm{RH}$, and $40 \pm 2^{\circ} \mathrm{C} / 75 \pm 5 \% \mathrm{RH}$ were evaluated for mean diameter, bulk density, tapped density, Carr's index, and angle of repose. No significant change in the stability parameters of FDIMs samples was observed after 15, 30, 45, and 60 days of storage, while there was a significant difference in parameters after 90 days of storage $\left({ }^{*} \mathrm{p}<0.05\right)$ at $25 \pm 2{ }^{\circ} \mathrm{C} / 60 \pm 5 \% \mathrm{RH}$ in comparison to storage at $40 \pm 2{ }^{\circ} \mathrm{C} / 75 \pm 5 \% \mathrm{RH}$. There was an insignificant difference in change in values of mean diameter, tapped density, and bulk density of samples placed at $25 \pm 2{ }^{\circ} \mathrm{C} / 60 \pm 5 \% \mathrm{RH}$ till 90 days. However, there was a significant increase in values of Carr's index and angle of repose of FDIM stored at $25 \pm 2^{\circ} \mathrm{C} / 60 \pm 5 \% \mathrm{RH}$ and $40 \pm 2^{\circ} \mathrm{C} / 75 \pm 5 \% \mathrm{RH}$, yet these values were below $15 \%$ and $25^{\circ}$, respectively (Figure 9) [7074].

\section{Conclusions}

This research work might provide a yardstick for manufacturing of FDIM of Trigonella foenum-graecum and Alpinia galanga extracts using PEG 6000, PVP K-30 and mannitol by simple solvent evaporation technique and freeze-drying and was optimized by Box-Behnken design. The present study concluded that optimized FDIMs of the herbal extract could be manufactured using 1:2 (w/w) herbal extract: polymer, $4.616 \% \mathrm{w} / \mathrm{v}$ mannitol, and $1.5 \% \mathrm{v} / \mathrm{v}$ surfactant which had a desirability function of 0.977 . The predicted response parameter values of optimized FDIMs were found at $1.326 \mu \mathrm{m}$ mean diameter and $0.244 \mathrm{~g} / \mathrm{cc}$ bulk density. Stability testing of optimized FDIM demonstrated that fabricated FDIMs were stable at room temperature conditions.

\section{Funding}

This research received no external funding.

\section{Acknowledgments}

The authors express gratitude to Chitkara College of Pharmacy, Chitkara University, Punjab, India, for motivational support to compile this research.

\section{Conflict of Interest}

The authors declare no conflict of interest.

\section{References}

1. Cukic, V.; Lovre, V.; Dragisic, D.; Ustamujic, A. Asthma and chronic obstructive pulmonary disease (COPD)-differences and similarities. Mater Sociomed. 2012, 24, 100, https://doi.org/10.5455/msm.2012.24.100-105.

2. Lee, W.H.; Loo, C.Y.; Traini, D.; Young, P.M. Inhalation of nanoparticle-based drug for lung cancer treatment: advantages and challenges. Asian J. Pharm. Sci. 2015, 10, 481-489, https://doi.org/10.1016/j.ajps.2015.08.009.

3. Mansour, H.M.; Rhee, Y.S.; Wu, X. Nanomedicine in pulmonary delivery. Int. J. Nanomedicine 2009, 4, 299-319, https://doi.org/10.2147/ijn.s4937.

4. Azarmi, S.; Tao, X.; Chen, H.; Wang, Z.; Finlay, W.H.; Löbenberg, R.; Roa, W.H. Formulation and cytotoxicity of doxorubicin nanoparticles carried by dry powder aerosol particles. Int. J. Pharm. 2006, 319, 155-161, https://doi.org/10.1016/j.ijpharm.2006.03.052. 
5. Paranjpe, M.; Müller-Goymann, C.C. Nanoparticle-mediated pulmonary drug delivery: a review. Int. J. Mol. Sci. 2014, 15, 5852-5873, https://doi.org/10.3390/ijms15045852.

6. Mehta, P.; Bothiraja, C.; Mahadik, K.; Kadam, S.; Pawar, A. Phytoconstituent based dry powder inhalers as biomedicine for the management of pulmonary diseases. Biomed. Pharmacother. 2018, 108, 828-837, https://doi.org/10.1016/j.biopha.2018.09.094.

7. Xia, Y.; Su, Y.; Wang, Q.; Yang, C.; Tang, B.; Zhang, Y.; Tu, J.; Shen, Y. Preparation, characterization, and pharmacodynamics of insulin-loaded fumaryl diketopiperazine microparticle dry powder inhalation. Drug Deliv. 2019, 26, 650-660, https://doi.org/10.1080/10717544.2019.1631408.

8. Ferkol, T.; Schraufnagel, D. The global burden of respiratory disease. Ann. Am. Thorac. Soc. 2014, 11, 404406, https://doi.org/10.1513/AnnalsATS.201311-405PS.

9. Borghardt, J.M.; Kloft, C.; Sharma, A. Inhaled therapy in respiratory disease: the complex interplay of pulmonary kinetic processes. Can. Respir. J. 2018, 2018, 1-18, https://doi.org/10.1155/2018/2732017.

10. Patil, J.S.; Sarasija, S. Pulmonary drug delivery strategies: A concise, systematic review. Lung India 2012, 29, 44-49, https://doi.org/10.4103/0970-2113.92361.

11. Alipour, S.; Montaseri, H.; Tafaghodi, M. Preparation and characterization of biodegradable paclitaxel loaded alginate microparticles for pulmonary delivery. Colloid Surface B. 2010, 81, 521-529, https://doi.org/10.1016/j.colsurfb.2010.07.050.

12. Wang, H.; Xu, Y.; Zhou, X. Docetaxel-loaded chitosan microspheres as a lung targeted drug delivery system: in vitro and in vivo evaluation. Int. J. Mol. Sci. 2014, 15, 3519-3532, https://doi.org/10.3390/ijms15033519.

13. Kim, I.; Byeon, H.J.; Kim, T.H.; Lee, E.S.; Oh, K.T.; Shin, B.S.; Lee, K.C.; Youn, Y.S. Doxorubicin-loaded porous PLGA microparticles with surface attached TRAIL for the inhalation treatment of metastatic lung cancer. Biomaterials. 2013, 34, 6444-6453, https://doi.org/10.1016/j.biomaterials.2013.05.018.

14. Zhu, L.; Li, M.; Liu, X.; Du, L.; Jin, Y. Inhalable oridonin-loaded poly (lactic-co-glycolic) acid large porous microparticles for in situ treatment of primary non-small cell lung cancer. Acta Pharm. Sin. B. 2017, 7, 8090, https://doi.org/10.1016/j.apsb.2016.09.006.

15. Chaurasiya, B.; Huang, L.; Du, Y.; Tang, B.; Qiu, Z.; Zhou, L.; Tu, J.; Sun, C. Size-based anti-tumoral effect of paclitaxel loaded albumin microparticle dry powders for inhalation to treat metastatic lung cancer in a mouse model. Int. J. Pharm. 2018, 542, 90-99, https://doi.org/10.1016/j.ijpharm.2018.02.042.

16. Li, Y.; Han, M.; Liu, T.; Cun, D.; Fang, L.; Yang, M. Inhaled hyaluronic acid microparticles extended pulmonary retention and suppressed systemic exposure of a short-acting bronchodilator. Carbohydr. Polym. 2017, 172, 197-204, https://doi.org/10.1016/j.carbpol.2017.05.020.

17. Ezhilarasi, P.N.; Karthik, P.; Chhanwal, N.; Anandharamakrishnan, C. Nanoencapsulation techniques for food bioactive components: a review. Food Bioproc. Tech. 2013, 6, 628-647, https://doi.org/10.1007/s11947012-0944-0.

18. Emami, F.; Vatanara, A.; Park, E.J.; Na, D.H. Drying technologies for the stability and bioavailability of biopharmaceuticals. Pharmaceutics. 2018, 10, 131, https://doi.org/10.3390/pharmaceutics10030131

19. Nafee, N.; Gaber, D.M.; Elzoghby, A.O.; Helmy, M.W.; Abdallah, O.Y. Promoted antitumor activity of myricetin against lung carcinoma via nanoencapsulated phospholipid complex in respirable microparticles. Pharm. Res. 2020, 37, 1-24, https://doi.org/10.1007/s11095-020-02794-z.

20. Reczyńska, K.; Marszałek, M.; Zarzycki, A.; Reczyński, W.; Kornaus, K.; Pamuła, E.; Chrzanowski, W. Superparamagnetic iron oxide nanoparticles modified with silica layers as potential agents for lung cancer treatment. J. Nanomater. 2020, 10, 1076, https://doi.org/10.3390/nano10061076.

21. Tewes, F.; Ehrhardt, C.; Healy, A.M. Superparamagnetic iron oxide nanoparticles (SPIONs)-loaded Trojan microparticles for targeted aerosol delivery to the lung. Eur. J. Pharm. Biopharm. 2014, 86, 98-104, https://doi.org/10.1016/j.ejpb.2013.09.004.

22. Cunha, L.; Rodrigues, S.; Rosa da Costa, A.M.; Faleiro, L.; Buttini, F.; Grenha, A. Inhalable chitosan microparticles for simultaneous delivery of isoniazid and rifabutin in lung tuberculosis treatment. Drug Dev. Ind. Pharm. 2019, 45, 1313-1320, https://doi.org/10.1080/03639045.2019.1608231.

23. Dufour, G.; Bigazzi, W.; Wong, N.; Boschini, F.; De Tullio, P.; Piel, G.; Cataldo, D.; Evrard, B. Interest of cyclodextrins in spray-dried microparticles formulation for sustained pulmonary delivery of budesonide. Int. J. Pharm. 2015, 495, 869-878, https://doi.org/10.1016/j.ijpharm.2015.09.052.

24. Mahmoud, A.A.; Elkasabgy, N.A.; Abdelkhalek, A.A. Design and characterization of emulsified spray dried alginate microparticles as a carrier for the dually acting drug roflumilast. Eur. J. Pharm. Sci. 2018, 122, 6476, https://doi.org/10.1016/j.ejps.2018.06.015. 
25. Hu, Y.; Li, M.; Zhang, M.; Jin, Y. Inhalation treatment of idiopathic pulmonary fibrosis with curcumin large porous microparticles. Int. J. Pharm. 2018, 551, 212-222, https://doi.org/10.1016/j.ijpharm.2018.09.031.

26. Jaspart, S.; Bertholet, P.; Piel, G.; Dogné, J.M.; Delattre, L.; Evrard, B. Solid lipid microparticles as a sustained release system for pulmonary drug delivery. Eur. J. Pharm. Biopharm. 2007, 65, 47-56, https://doi.org/10.1016/j.ejpb.2006.07.006.

27. Dimer, F.; de Souza Carvalho-Wodarz, C.; Haupenthal, J.; Hartmann, R.; Lehr, C.M. Inhalable clarithromycin microparticles for treatment of respiratory infections. Pharm. Res. 2015, 32, 3850-3861, https://doi.org/10.1007/s11095-015-1745-8.

28. Gallo, L.; Bucalá, V.; Ramírez-Rigo, M.V. Formulation and characterization of polysaccharide microparticles for pulmonary delivery of sodium cromoglycate. AAPS J. 2017, $18, \quad 1634-$ 1645, https://doi.org/10.1208/s12249-016-0633-9.

29. Muttil, P.; Kaur, J.; Kumar, K.; Yadav, A.B.; Sharma, R.; Misra, A. Inhalable microparticles containing large payload of anti-tuberculosis drugs. Eur. J. Pharm. Sci. 2007, 32, 140-150, https://doi.org/10.1016/j.ejps.2007.06.006.

30. Salama, R.; Hoe, S.; Chan, H.K.; Traini, D.; Young, P.M. Preparation and characterization of controlled release co-spray dried drug-polymer microparticles for inhalation 1: Influence of polymer concentration on physical and in vitro characteristics. Eur. J. Pharm. Biopharm. 2008, 69, 486-495, https://doi.org/10.1016/j.ejpb.2007.12.019.

31. Mezzena, M.; Scalia, S.; Young, P.M.; Traini, D. Solid lipid budesonide microparticles for controlled release inhalation therapy. AAPS J. 2009, 11, 771-778, https://doi.org/10.1208/s12248-009-9148-6.

32. Naikwade, S.R.; Bajaj, A.N.; Gurav, P.; Gatne, M.M.; Soni, P.S. Development of budesonide microparticles using spray-drying technology for pulmonary administration: design, characterization, in vitro evaluation, and in vivo efficacy study. AAPS Pharm. Sci. Tech. 2009, 10, 993-1012, https://doi.org/10.1208/s12249-0099290-6.

33. Li, Y.Z.; Sun, X.; Gong, T.; Liu, J.; Zuo, J.; Zhang, Z.R. Inhalable microparticles as carriers for pulmonary delivery of thymopentin-loaded solid lipid nanoparticles. Pharm. Res. 2010, 27, 1977-1986, https://doi.org/10.1007/s11095-010-0201-z.

34. Pai, R.V.; Jain, R.R.; Bannalikar, A.S.; Menon, M.D. Development and evaluation of chitosan microparticles based dry powder inhalation formulations of rifampicin and rifabutin. J. Aerosol Med. Pulm. Drug Deliv. 2016, 29, 179-195, https://doi.org/10.1089/jamp.2014.1187.

35. Mishra, M.; Mishra, B. Mucoadhesive microparticles as potential carriers in inhalation delivery of doxycycline hyclate: a comparative study. Acta Pharm. Sin. B. 2012, 2, 518-526, https://doi.org/10.1016/j.apsb.2012.05.001.

36. Srinivasan, K. Fenugreek (Trigonella foenum-graecum): A review of health beneficial physiological effects. Food Reviews Int. 2006, 22, 203-224, https://doi.org/10.1080/87559120600586315.

37. Bin-Hafeez, B.; Haque, R.; Parvez, S.; Pandey, S.; Sayeed, I.; Raisuddin, S. Immunomodulatory effects of fenugreek (Trigonella foenum graecum L.) extract in mice. Int. Immunopharmacol. 2003, 3, 257-265, https://doi.org/10.1016/S1567-5769(02)00292-8.

38. Chouni, A.; Paul, S. A review on phytochemical and pharmacological potential of Alpinia galanga. Pharmacogn. J. 2018, 10, 9-15, https://doi.org/10.5530/pj.2018.1.2.

39. Khattak, S.; Shah, H.U.; Ahmad, W.; Ahmad, M. Biological effects of indigenous medicinal plants Curcuma longa and Alpinia galanga. Fitoterapia. 2005, 76, 254-257, https://doi.org/10.1016/j.fitote.2004.12.012.

40. Shahin, H.I.; Vinjamuri, B.P.; Mahmoud, A.A.; Shamma, R.N.; Mansour, S.M.; Ammar, H.O.; Ghorab, M.M.; Chougule, M.B.; Chablani, L. Design and evaluation of novel inhalable sildenafil citrate spray-dried microparticles for pulmonary arterial hypertension. J. Control. Release 2019, 302, 126-139, https://doi.org/10.1016/j.jconrel.2019.03.029.

41. Moura, C.; Casimiro, T.; Costa, E.; Aguiar-Ricardo, A. Optimization of supercritical CO2-assisted spray drying technology for the production of inhalable composite particles using quality-by-design principles. Powder Technol. 2019, 357, 387-397, https://doi.org/10.1016/j.powtec.2019.08.090.

42. Zhang, L.; Zhang, X.; Li, J.; Beck-Broichsitter, M.; Muenster, U.; Wang, X.; Zhao, J.; Mao, S. Optimization of budesonide-loaded large-porous microparticles for inhalation using quality by design approach. J. Drug Deliv. Sci. Technol. 2019, 53, 101140, https://doi.org/10.1016/j.jddst.2019.101140.

43. Soni, G.; Yadav, K.S.; Gupta, M.K. QbD based approach for formulation development of spray dried microparticles of erlotinib hydrochloride for sustained release. J. Drug Deliv. Sci. Technol. 2020, 57, 101684, https://doi.org/10.1016/j.jddst.2020.101684. 
44. Soni, G.; Yadav, K.S.; Gupta, M.K. Design of experiments (DoE) approach to optimize the sustained release microparticles of gefitinib. Curr. Drug Deliv. 2019, 16, 364-374, https://doi.org/10.2174/1567201816666181227114109.

45. Sankhyan, A.; Pawar, P.K. Metformin loaded non-ionic surfactant vesicles: optimization of formulation, effect of process variables and characterization. DARU J. Pharm. Sci. 2013, 21, 1-8, https://doi.org/10.1186/2008-2231-21-7.

46. Vishwa, B.; Moin, A.; Gowda, D.V.; Rizvi, S.; Hegazy, W.A.; Abu Lila, A.S.; Khafagy, E.S.; Allam, A.N. Pulmonary targeting of inhalable moxifloxacin microspheres for effective management of tuberculosis. Pharmaceutics. 2021, 13, 79, https://doi.org/10.3390/pharmaceutics13010079.

47. Rad, R.T.; Dadashzadeh. S.; Vatanara, A.; Alavi, S.; Ghasemian, E.; Mortazavi, S.A. Tadalafil nanocomposites as a dry powder formulation for inhalation, a new strategy for pulmonary arterial hypertension treatment. Eur. J. Pharm. Sci. 2019, 133, 275-286, https://doi.org/10.1016/j.ejps.2019.04.001.

48. Shah, S.; Cristopher, D.; Sharma, S.; Soniwala, M.; Chavda, J. Inhalable linezolid loaded PLGA nanoparticles for treatment of tuberculosis: design, development and in vitro evaluation. J. Drug Deliv. Sci. Technol. 2020, 60, 102013, https://doi.org/10.1016/j.jddst.2020.102013.

49. Reeta, B.; Vivek, S.; Jain, U.K. Assessment of antigen stabilizing potential of saponin enriched extract from Trigonella foenum graecum at water in oil interface for encapsulation in polymeric microspheres. Int. J. Pharmtech Res. 2013, 5, 271-274.

50. Faghihi, H.; Darabi, M.; Mirmoeini, M.; Vatanara, A. Formulation and evaluation of inhalable microparticles of Rizatriptan Benzoate processed by spray freeze-drying. J. Drug Deliv. Sci. Technol. 2021, 62, 102356. https://doi.org/10.1016/j.jddst.2021.102356.

51. Emami, F.; Vatanara, A.; Vakhshiteh, F.; Kim, Y.; Kim, T.W.; Na, D.H. Amino acid-based stable adalimumab formulation in spray freeze-dried microparticles for pulmonary delivery. J. Drug Deliv. Sci. Technol. 2019, 54, 101249, https://doi.org/10.1016/j.jddst.2019.101249.

52. Nemati, E.; Mokhtarzadeh, A.; Panahi-Azar, V.; Mohammadi, A.; Hamishehkar, H.; Mesgari-Abbasi, M.; Dolatabadi, J.E.' de la Guardia, M. Ethambutol-loaded solid lipid nanoparticles as dry powder inhalable formulation for tuberculosis therapy. AAPS PharmSciTech. 2019, 20, 1-9, https://doi.org/10.1208/s12249019-1334-y.

53. Abdel-Gawad, R.; Osman, R.; Awad, G.A.; Mortada, N. Lecithin-based modified soft agglomerate composite microparticles for inhalable montelukast: Development, tolerability and pharmacodynamic activity. Powder Technol. 2020, 360, 1167-1176, https://doi.org/10.1016/j.powtec.2019.11.029.

54. Luo, Y.; Zhang, Z.; Huang, G.; Yu, H.; Ma, Y.; Zheng, Q.; Yue, P. Roles of maltodextrin and inulin as matrix formers on particle performance of inhalable drug nanocrystal-embedded microparticles. Carbohydr. Polym. 2020, 235, 115937, https://doi.org/10.1016/j.carbpol.2020.115937.

55. Khatoon, H.; Rai, J.P. Optimization studies on biodegradation of atrazine by Bacillus badius ABP6 strain using response surface methodology. Biotechnol. Rep. 2020, 26, e00459, https://doi.org/10.1016/j.btre.2020.e00459.

56. Patel, R.B.; Patel, M.R.; Patni, N.R.; Agrawal, V. Efinaconazole: DoE-supported development and validation of a quantitative HPTLC method and its application for the assay of drugs in solution and microemulsionbased formulations. Anal. Methods. 2020, 12, 1380-1388, https://doi.org/10.1039/C9AY02599E.

57. Rashid, F.; Ahmed, Z.; Hussain, S.; Kausar, T.; Nadeem, M.; Ainee, A.; Mehmood, T. Optimization of fenugreek and flax polysaccharides-based edible coating formulation to preserve the quality and storability of apple after harvesting. J. Food Process. Preserv. 2020, 44, e14812, https://doi.org/10.1111/jfpp.14812.

58. Achim, M.A.; Tefas, L.R.; Iovanov, R.A.; Vonica-Gligor, A.L.; Barbu-Tudoran, L.U.; Tomuță, I.O. Preparation and in vitro evaluation of felodipine loaded poly ( $\varepsilon$-caprolactone) microspheres: Quality by Design approach. Farm. 2019, 67, 670-683.

59. Haider, M.; Elsayed, I.; Ahmed, I.S.; Fares, A.R. In situ-forming microparticles for controlled release of rivastigmine: in vitro optimization and in vivo evaluation. Pharmaceuticals. 2021, 14, 66, https://doi.org/10.3390/ph14010066.

60. Chappidi, S.R.; Bhargav, E.; Marikunte, V.; Chinthaginjala, H.; Jyothi, M.V.; Pisay, M.; Jutur, M.; Mahammad, M.S.; Poura, M.; Yadav, S.; Syed, M. A cost effective (QbD) approach in the development and optimization of rosiglitazone maleate mucoadhesive extended-release tablets-in vitro and ex vivo. $A d v$. Pharm. Bull. 2019, 9, 281, https://doi.org/10.15171/apb.2019.032. 
61. Jain. D.; Sodani, A.; Ray, S.; Ghosh, P.; Nandi, G. Formulation of extended-release beads of lamotrigine based on alginate and cassia fistula seed gum by QbD approach. Curr. Drug Deliv. 2020, 17, 422-437, https://doi.org/10.2174/1567201817666200317124022.

62. Pandya, A.; Athawale, R.; Puro, D.; Bhagwat, G. Design and evaluation of long-acting biodegradable plga microspheres for ocular drug delivery. Nanoscience \& Nanotechnology-Asia. 2021, 11, 53-66, https://doi.org/10.2174/2210681210666191223144755.

63. Abou-ElNour, M.; Ishak, R.A.; Tiboni, M.; Bonacucina, G.; Cespi, M.; Casettari, L.; Soliman, M.E.; Geneidi, A.S. Triamcinolone acetonide-loaded PLA/PEG-PDL microparticles for effective intra-articular delivery: synthesis, optimization, in vitro and in vivo evaluation. J. Controlled Release. 2019, 309, 125-144, https://doi.org/10.1016/j.jconrel.2019.07.030.

64. Garud, N.; Garud, A. Preparation and in-vitro evaluation of metformin microspheres using non-aqueous solvent evaporation technique. Trop. J. Pharm. Res. 2012, 11, 577-583, https://doi.org/10.4314/tjpr.v11i4.8.

65. Lamy, B.; Serrano, D.R.; O'connell, P.; Couet, W.; Marchand, S.; Healy, A.M.; Tewes, F. Use of leucine to improve aerodynamic properties of ciprofloxacin-loaded maltose microparticles for inhalation. EJPMR. 2019, 1, 2-11, https://doi.org/10.34154/2019-EJPR.01(01).pp-02-11/euraass.

66. Chime, S.A.; Akpa, P.A.; Ugwuanyi, C.C.; Attama, A.A. Anti-inflammatory and gastroprotective properties of aspirin-entrapped solid lipid microparticles. Recent Pat. Inflamm. Allergy Drug Discov. 2020, 14, 78-88, https://doi.org/10.2174/1872213X14666200108101548.

67. Yang, Z.; Wang, L.; Tian, L.; Zhang, X.; Huang, G. Tadalafil-loaded PLGA microspheres for pulmonary administration: preparation and evaluation. Brazilian J. Pharm. Sci. 2019, 55, https://doi.org/10.1590/s217597902019000217536.

68. Baghdan, E.; Duse, L.; Schüer, J.J.; Pinnapireddy, S.R.; Pourasghar, M.; Schäfer, J.; Schneider, M.; Bakowsky, U. Development of inhalable curcumin loaded Nano-in-Microparticles for bronchoscopic photodynamic therapy. Eur. J. Pharm. Sci. 2019, 132, 63-71, https://doi.org/10.1016/j.ejps.2019.02.025.

69. Almansour, K.; Alfagih, I.M.; Ali, R.; Elsayed, M.M. Inhalable microparticles containing terbinafine for management of pulmonary fungal infections: Spray drying process engineering using lactose vs. mannitol as excipients. J. Drug Deliv. Sci. Technol. 2020, 60, 101991, https://doi.org/10.1016/j.jddst.2020.101991.

70. Phutane, P.; Lotlikar, V.; Ghule, A.; Sutar, S.; Kadam, V.; Shidhaye, S. In vitro evaluation of novel sustained release microspheres of glipizide prepared by the emulsion solvent diffusion-evaporation method. J. Young Pharm. 2010, 2, 35-41, https://doi.org/10.4103/0975-1483.62210.

71. Behera, B.C.; Sahoo, S.K.; Dhal, S.; Barik, B.B.; Gupta, B.K. Characterization of glipizide-loaded polymethacrylate microspheres prepared by an emulsion solvent evaporation method. Trop. J. Pharm. Res. 2008, 7, 879-885, https://doi.org/10.4314/tjpr.v7i1.14672.

72. Bakhtiary, Z.; Barar, J.; Aghanejad, A.; Saei, A.A.; Nemati, E.; Ezzati Nazhad Dolatabadi, J.; Omidi, Y. Microparticles containing erlotinib-loaded solid lipid nanoparticles for treatment of non-small cell lung cancer. Drug Dev. Ind. Pharm. 2017, 43, 1244-1253, https://doi.org/10.1080/03639045.2017.1310223.

73. Puthli, S.; Vavia, P.R. Stability studies of microparticulate system with piroxicam as model drug. AAPS PharmSciTech. 2009, 10, 872-880, https://doi.org/10.1208/s12249-009-9280-8.

74. Solanki, N.R.; Patel, D.H.; Talele, D.R. Dextran microparticulate inhalable dry powder for the treatment of cystic fibrosis and mucopolysaccharidosis. Curr. Drug Deliv. 2020, 17, 218-228, https://doi.org/10.2174/1567201817666200122160110. 